Jurnal Mandala Pharmacon Indonesia, Vol 6.No.2 Desember 2020

Avaiable online at www.jurnal-pharmaconmw.com/jmpi

p-ISSN : 2442-6032

$e$-ISSN : 2598-9979

\title{
Aktivitas Antimikroba Ekstrak Etanol Daun Cabai Rawit Spesies Capsicum frutescens Linn dan Capsicum annum pada Staphylococcus aureus
}

Jamal Saripa, Silviana Hasanuddin, Muhammad Isrul

Prodi Farmasi, STIKES Mandala Waluya Kendari

\begin{abstract}
ABSTRAK
Penyakit infeksi saat ini menjadi masalah yang serius, ditambah lagi dengan semakin meluasnya resistensi mikroba terhadap obat-obatan yang ada. Penyakit infeksi ini sering di jumpai pada anak karena daya tahan kulit terhadap invasi kuman pathogen belum sesempurna orang dewasa. Cabai merupakan jenis tanaman suku terung-terungan (Solanaceae) sejak lama dimanfaakan untuk mengobatan beberapa penyakit. Tujuan penelitian ini bertujuan untuk mengetahui aktivitas antibakteri dan konsentrasi efektif anti bakteri antara ekstrak daun Cabai Rawit Spesies Capsicum frutescens Linn dengan cabai rawit spesies Capsicum annum terhadap pertumbuhan Staphylococcus aureus dan Candida albicans.Pengujian aktivitas antimikroba menggunakan metode difusi agar. Sampel penelitian adalah ekstrak etanol daun cabai rawit spesies Capsicum frutescens Linn dan Capsicum annum dengan menggunakan 4 variasi konsentrasi yaitu $5 \%, 10 \%, 25 \%$ dan $40 \%$ dengan kontrol positif tetrasiklin dan kontrol negatif dimethylsulfoksida, kemudian analisis data menggunakan One-Way ANOVA. Hasil penelitian

menunjukkan bahwa ekstrak etanol daun cabai rawit spesies Capsicum frutescens Linn memiliki aktivitas daya hambat terhadap taphylococcus aureuspada konsentrasi $5 \%$ yaitu sebesar 1,6 $\mathrm{mm} \pm 0,17$, konsentrasi 10\% sebesar 2,5 $\mathrm{mm} \pm 0,40$, konsentrasi $20 \%$ sebesar 3,2 $\mathrm{mm} \pm 0,05$ dan konsentrasi 40\% sebesar4,2 $\mathrm{mm} \pm 0,05$. Sedangkan ekstrak etanol daun cabai rawit spesies Capsicum annum memiliki aktivitas daya hambat pada konsentrasi $5 \%$ sebesar 5,8 $\mathrm{mm} \pm 0,52$, konsentrasi $10 \%$ sebesar $7,8 \mathrm{~mm} \pm 1,01$, konsentrasi $20 \%$ sebesar $13,0 \quad \mathrm{~mm} \pm 1,1$, konsentrasi $40 \%$ sebesar $20,2 \mathrm{~mm} \pm 1,0$. Zona hambat yang ditunjukkan oleh tetrasiklin $1 \%$ sebagai kontrol positif sebesar 29,0 $\mathrm{mm} \pm 1,2$.

Kata Kunci: Capsicum frutescens Linn, Capsicum annum, Staphylococcus aureus

\section{Penulis Korespondensi :}

Silviana Hasanuddin

Program Studi Farmasi, STIKES Mandala Waluya Kendari

E-mail : silviana.hasanuddin@gmail.com
\end{abstract}

\section{PENDAHULUAN}

Infeksi kulit adalah masalah utama penyebab tingginya angka morbiditas pada anak-anak terutama di negaranegara berkembang dan wilayah beriklim tropis. Prevalensi terinfeksi Staphylococcus aureus Sekitar 30\% dari populasi manusia, umumnya terdapat pada kulit, saluran pencernaan dan saluran pernapasan tanpa menyebabkan masalah kesehatan. Bakteri ini menyebabkan masalah ketika terdapat suatu fokus infeksi dan dapat pula

menyebar satu orang ke orang lain melalui objek yang terkontaminasi atau melalui kontak langsung atau (Jawetz et al., 2005; Zeller, 2011; Tong et al., 2015). Penyakit infeksi kulit yang disebabkan oleh Staphylococcus aureus selulit, erysipelas, impetigo, foliculitis, furuncle, carbuncle (radangkulit), dan bisul (Leboffe, 2011).

Staphylococcus aureus adalah termasuk dari bakteri kokus gram positif, bakteri ini juga ditemukan sebagai bakteri 
flora normal pada manusia. Staphylococcus aureus dapat menjadi penyebab infeksi baik pada manusia maupun pada hewan. Infeksi yang disebabkan oleh Staphylococcus aureus dapat berkembang hingga menjadi infeksi sistemik yang parah. Habitat Staphylococcus aureus biasanya ada di rongga hidung. Dari rongga hidung, Staphylococcus aureus dapat pula berpidah dan menyebar kekulit maupun bagian tubuh lainnya. Koloni Staphylococcus aureus juga dapat ditemukan di usus, tenggorokan, lipatan kulit (ketiak) vagina dan perineum. Infeksi yang disebabkan Staphylococcus aureus dapat menjadi masalah penting bagi kesehatan. Hal ini dikarenakan beberapa kasus resistensi pada antibiotik. Selain karena resistensi, pengguna antibiotik memerlukan biaya yang belum tentu dapat dicapai oleh masyarakat umum (Rahardjo, 2017).

Beberapa efek samping yang di timbulkan antibiotik diatas yang mendasari peneliti untuk melakukan penelitian dengan bahan alam yang di harapkan dapat memberikan informasi alternatif terapi. Sampel bahan alam yang peneliti gunakan adalah Cabai Rawit Spesies Capsicum frutescens Linn dan Capsicum annum.

Cabai sudah sejak lama dibudidayakan di Indonesia karena mempunyai nilai ekonomis yang tinggi. Cabai juga sering digunakan dalam memenuhi kebutuhan rumah tangga yaitu sebagai pelengkap bumbu masak. Cabai berasal dari genus Capsicum, diakui sebagai salah satu keluarga Solanaceae yang paling dominan dan tersebar secara global. Capsicum mempunyai genus yang beragam, terdiri dari lebih dari 31 spesies yang berbeda termasuk lima spesies peliharaan yaitu $C$. annuum, $C$. pubescen, $C$. frutescens Capsicum baccatum $\operatorname{dan} C$. chinense (Batih, et al, 2020). Cabai kaya akan karbohidrat flavonoid, vitamin (vitamin $\mathrm{C}$, vitamin $\mathrm{E}$, dan vitamin $\mathrm{B}$ ), capsaicin, lemak, mineral, air, protein dan serat. Cabai juga mengandung senyawa antioksidan antara lain vitamin $\mathrm{K}$, fitosterol, beta karoten dan beta cryptoxanchin (Anggraeni, 2013).

Dari berbagai jenis cabai tersebut sering ditemukan kemiripan dan perbedaan terutama antara cabai rawit Spesies Capsicum frutescens Linn dan Capsicum annum. Dengan adanya laporan kemiripan dan perbedaan jenisjenis cabai tersebut, dapat dikembangkan menjadi sebuah penelitian baru tentang perbedaan aktivitas antimikroba antara cabai rawit Spesies Capsicum frutescens Linn dan Capsicum annum (Anggraeni, 2013).

Variabilitas kandungan fitokimia dari dua spesies Capsicum

yang dibudidayakan terkait erat, $C$. annuum dan $C$. frutescens, diperiksa sebagai alat tambahan untuk menetapkan keterkaitan filogenetik mereka dan untuk tujuan pemuliaan (Olatunji dan Afolayan, 2019). Penilitian yang di lakukan Yunita tahun 2012. Mengatakan bahwa cabai rawit Spesies Capsicum frutescens Linn memiliki kandungan senyawa glikon dan flavanoid yang diketahui memiliki aktifitas antibakteri dan anti jamur dan Fraksi teraktif yang terdapat pada daun cabai rawit ialah flavonoid dan glikon (Yunita, 2012).

\section{BAHAN DAN METODE Bahan}

Bahan yang digunakan dalam penilitian ini adalah ekstrak etanol daun cabairawitSpesiesCapsicum frutescens Linn dan Capsicum annum, Tetrasiklin, DMSO, aquadest, $\mathrm{NaCl}$, Streptococcus aureus, Nutrient Agar (NA) 


\section{Metode Penelitian}

Penyiapan sampel

Daun cabai rawit spesies Capsicum frutescens Linn dan Capsicum annum diambil pada pagi hari pukul 09.00 di konda Konawe Selatan, Provinsi Sulawesi Tenggara. Sampel dicuci bersih dengan air mengalir, dipotong kecil kemudian dikeringkan setelah itu sampel diblender kasar.

Ekstraksi yang dilakukan menggunakan metode maserasi. Serbuk kering daun cabai rawit dimaserasi selama 3x24 jam pada suhu kamar dengan pelarut etanol 96\%. Kemudian Maserat disaring guna memisahkan antara residu dan filtrat. Filtrat yang diperoleh diuapkan menggunakan rotary evaporator sehingga diperoleh maserat kental (ekstrak etanol) (Doughari, 2012; Isrul, 2019).

\section{Identifikasi GolonganSenyawa Kimia}

\section{Pemeriksaan alkaloid}

Ekstrak diambil sebanyak $2 \mathrm{~mL}$ diuapkan pada cawan porselin sampai didapatkan residu. Residu kemudian dilarutkan menggunakan $5 \mathrm{~mL} \mathrm{HCl} 2 \mathrm{~N}$. Larutan yang telah didapat dibagi kedalam 3 tabung reaksi. Tabung pertama ditambahkan $\mathrm{HCl} 2 \mathrm{~N}$ yang berfungsi sebagai blanko. Tabung kedua ditambahkan Dragendorff 3 tetes dan tabung ketiga ditambah pereaksi Mayer 3 tetes. Terbentuknya endapan putih dan endapan jingga menunjukkan adanya alkaloid (Idadi dkk., 2013).

\section{Pemeriksaan sterol dan triterpenoid}

Ekstrak ditambahkan dengan 0,5 mL kloroform dan 0,5 mL asam asetat anhidrat. Kemudian, larutan ditetesi 2 $\mathrm{mL}$ asam sulfat pekat. Warna hijau kebiruan menandakan positif sterol. Jika hasil berupa cincin kecokelatan atau violet pada perbatasan dua pelarut, menunjukkan positif adanya triterpenoid (Idadi dkk., 2013).

\section{Pemeriksaan saponin}

Ekstrak uji dimasukkan kedalam tabung reaksi, ditambahkan aquadest 10 mL dan d panaskan, dinginkan kemudian dikocok kuat selama 10 detik. Terbentuk buih yang menetap selama 10 menit setinggi 1-10 $\mathrm{cm}$ dan bila dilakukan penambahan $\mathrm{HCl} 2 \mathrm{~N}$, buih tidak hilang (Idadi dkk., 2013).

\section{Pemeriksaan flavonoid}

Ekstrak $1 \mathrm{ml}$ diuapakan sampai kering, lalu ditambahkan aseton, asam borat, dan asam oksalat, diuapkan hatihati di atas tangas air. Sisa ditambahkan $10 \mathrm{ml}$ eter, kemudian diamati dibawah sinar UV $366 \mathrm{~nm}$. Jika terlihat pendaran warna kuning intensif menunjukkan adanya senyawa flavanoid (Winarti dkk, 2007).

\section{Pemeriksaan tanin}

Ekstrak $1 \mathrm{mg}$ ditambahkan etanol 96\% hingga sampel terendam seluruhnya. Kemudian ditambahkan 2 hingga 3 tetes larutan $\mathrm{FeCl}_{3}$ 1\%. Hasil yang positif ditunjukkan bila terbentuknya warna hijau atau hitam kebiruan (Marlinda dkk, 2012).

PengujianAktivitas antibakteri

\section{Sterilisasi Alat dan Media Penelitian}

Tabung tabung reaksi, vial, dan cawan petri dibungkus menggunakan kertas lalu dimasukkan kedalam oven pada suhu $180^{\circ} \mathrm{C}$ selama 2 jam. Sedangkan alat yang berskala seperti spoit dimasukkan dalam autoklaf dengan suhu $121^{\circ} \mathrm{C}$ selama 15 menit. Sedangkan alat seperti pinset dan ose dibakar dengan pembakaran diatas api langsung (Ortez, 2005). 
Pembuatan Nutrient Agar (NA) denganc ditimbang 3,3 gram NA, dilarutkan dalam $165 \mathrm{ml}$ aquadest, dipanaskan, kemudian disterilkan di autoklaf elama 15 menit pada suhu $121^{\circ} \mathrm{C}$. Media NA siap digunakan untuk pertumbuhan bakteri Staphylococcus aureus (Sugianto, 2012).

Staphylococcus aureus dibiakkan pada media NA yang telah memadat di dalam tabung reaksi, dan diinkubasi pada suhu $35^{\circ}-37^{\circ} \mathrm{C}$ selama $18-24$ jam. Kemudian diambil 1 inokulum, di masukkan kedalam tabung reaksi yang berisi $10 \mathrm{ml} \mathrm{NaCl}$ dan Suspensi bakteri siap digunakan untuk uji aktivitas antibakteri.

\section{Uji aktivitas zona} hambatAntibakteri

Media NA yang telah disterilkan di masukkan kedalam tabung reaksi sebanyak $15 \mathrm{ml}$, di tambahkan $1 \mathrm{ml}$ suspensi bakteri, di homogenkan, kemudian di masukkan kedalam cawan petri dan di biarkan hingga memadat. Paper disk yang telah berisi Ektrak etanol $5 \%, 10 \%, 25 \%$ dan $40 \%$ di masukan kedalam plat agar bagian pertama sedangkan paper disk yang berisi kontrol (+) Tetrasiklin dan kontrol (-) DMSO di masukkan kedalam plat agar bagian kedua. Kemudian di inkubasi di dalam incubator pada suhu $35^{\circ} \mathrm{C}-37^{\circ} \mathrm{C}$ selama 18-24 jam. Masing-masing plat bakteri dikeluarkan dari inkubator, di amati luas daerah hambatan pertumbuhan baketeri dan di ukur zona hambat yang terjadi.

\section{HASIL DAN PEMBASAHAN}

Hasil pengujian skrining Capsicum frutescens Linn dan Capsicum annum.

Tabel 1. Hasil Identifikasi Golongan Senyawa ekstrak etanol daun cabai spesies Capsicum frutescens Linn dan Capsicum annum.

\begin{tabular}{|c|c|c|}
\hline Senyawa & Sampel & Hasil \\
\hline Alkaloid & \multirow{5}{*}{$\begin{array}{l}\text { Capsicum } \\
\text { frutescens } \\
\text { Linn }\end{array}$} & Positif(+) \\
\hline Tanin & & Positif (+) \\
\hline Saponin & & Positif (+) \\
\hline Flavanoid & & Positif(+) \\
\hline Triterpenoid & & Positif (+) \\
\hline Alkaloid & \multirow{5}{*}{$\begin{array}{l}\text { Capsicum } \\
\text { annum }\end{array}$} & Positif(+) \\
\hline Tanin & & Positif (+) \\
\hline Saponin & & Positif (+) \\
\hline Flavanoid & & Positif (+) \\
\hline Triterpenoid & & Positif (+) \\
\hline
\end{tabular}

Hasil Ekstraksi Daun Cabai Spesies Capsicum frutescens Linn.

Tabel2. Ekstrak Daun Cabai Spesies Capsicum frutescens Linn.

\begin{tabular}{ccc}
\hline Simplisia & Ekstrak & $\begin{array}{c}\text { Rendamen } \\
(\%)\end{array}$ \\
\hline $300 \mathrm{~g}$ & $110,23 \mathrm{~g}$ & 36,74 \\
\hline
\end{tabular}

Hasil Ekstraksi Daun Cabe Rawit Spesies Capsicum annum.

Tabel 3. Ekstrak Daun Cabai Spesies Capsicum annum.

\begin{tabular}{ccc}
\hline Simplisia & Ekstrak & $\begin{array}{c}\text { Rendamen } \\
(\%)\end{array}$ \\
\hline $300 \mathrm{~g}$ & $100,15 \mathrm{~g}$ & 33,50 \\
\hline
\end{tabular}
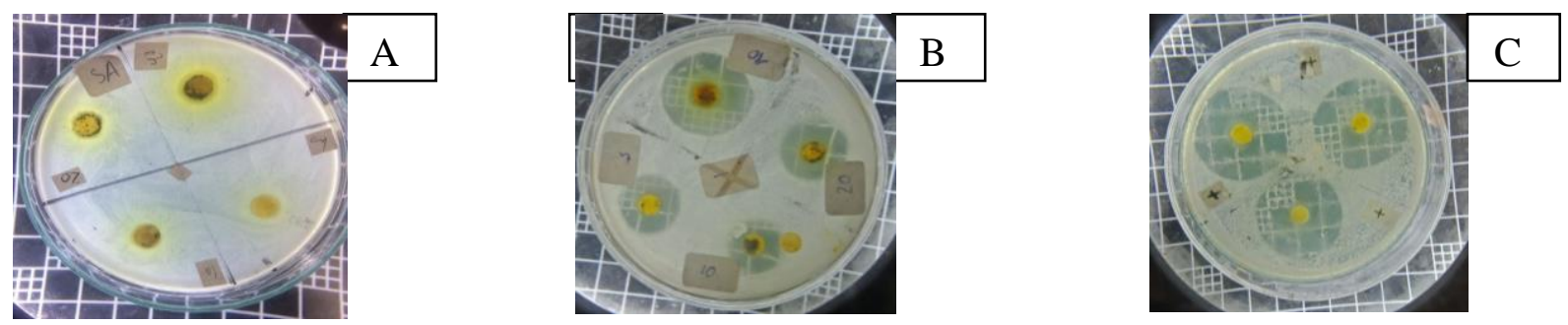

Gambar 1. A.Zona Hambat ekstrak etanol daun cabai spesies Capsicum frutescens Linn. B.Zona Hambat ekstrak etanol daun cabai spesies Capsicum annum. C.Zona hambat control positif Tetrasiklin 
Tabel 4. Hasil pengukuran diameter zona hambat ekstrak etanol daun cabai rawit spesies Capsicum frutescens Linn dan Capsicum annum.

\begin{tabular}{|c|c|c|l|}
\hline Sampel & Konsentrasi (\%) & $\begin{array}{c}\text { Rata-rata } \\
\text { hasilpengamatan } \\
(\mathrm{mm})\end{array}$ & $\begin{array}{c}\text { Kategori zona } \\
\text { Hambat }\end{array}$ \\
\hline \multirow{3}{*}{$\begin{array}{c}\text { Capsicum } \\
\text { frutescens Linn }\end{array}$} & 5 & $1,6 \pm 0,17$ & Lemah \\
\cline { 2 - 4 } & 10 & $2,5 \pm 0,40$ & Lemah \\
\cline { 2 - 4 } & 20 & $3,2 \pm 0,05$ & Lemah \\
\hline \multirow{3}{*}{$\begin{array}{c}\text { Capsicum } \\
\text { annum }\end{array}$} & 40 & $4,2 \pm 0,05$ & Lemah \\
\cline { 2 - 4 } & 10 & $5,8 \pm 0,52$ & Sedang \\
\cline { 2 - 4 } & 20 & $7,8 \pm 1,01$ & Sedang \\
\hline Tetrasiklin & 40 & $20,2 \pm 1,0$ & Sangat kuat \\
\hline DMSO & & $29,0 \pm 1,2$ & Sangat kuat \\
\hline
\end{tabular}

$\begin{array}{ll}\text { Keterangan : } & \\ 5 \% & : \text { EkstrakDenganKonsentrasi (5\%) } \\ 10 \% & : \text { EkstrakDenganKonsentrasi (10\%) } \\ 20 \% & : \text { EkstrakDenganKonsentrasi (20\%) } \\ 40 \% & : \text { EkstrakDenganKonsentrasi (40\%) } \\ \text { Tetrasiklin } & : \text { KontrolPositif } \\ \text { DMSO } & : \text { KontrolNegatif }\end{array}$

Penelitian uji aktivitas ekstrak etanol daun cabai rawitspesiesCapsicum frutescens Linn dan Capsicum annumdimaksudkan untuk mengetahui konsentrasidaya hambat ekstrak etanol yang memiliki potensi dalam menghambat Staphylococcus aureus. Sampel yang telah diperoleh kemudian dicuci dengan air mengalir hingga bersih dengan tujuan untuk menghilangkan atau mengurangi tanah dan debu yang melekat pada daun, kemudian sampel dirajang untuk memperkecil ukuran sampel, kemudian sampel dikeringkan dengan cara diangin-anginkan tidak terkena sinar matahari langsung, setelah kering sampel dilakukan untuk proses ekstraksi.

Sampel daun cabai dibuat ekstrak dengan metode maserasimenggunakan pelarut etanol 96\%. Etanol digunakan karna bersifat polar dan universal. Etanol juga merupakan pelarut untuk zat organik maupun anorganik. Etanol 96\% diharapkan dapat menarik senyawa metabolit sekunder yang lebih banyak. Karna apabila konsentrasi etanol yang digunakan semakin tinggi, maka akan semakin mudah dalam proses pemisahan senyawa metabolit sekunder dari sampel (Martono et al., 2012).

Proses maserasi dilakukan selama 3 hari dan ekstrak yang didapat selanjutnya dipisahkan dengan pelarutnya menggunakan rotary evaporator vakum dan didapatkan ekstrak kental etanol berwarna hijau pekat sebanyak 300 gr dan berat rendamen $36 \%$. Nilai rendamen yang tinggi menunjukan proses ekstraksi zat aktif berlangsung efektif. Proses maserasi dipilih karena senyawa yang ingin ditarik adalah senyawa flavonoid dimana senyawa tersebut tidak tahan akan pemanasan sehingga digunakan metode maserasi, metode ini tidak memerlukan pemanasan sehingga cocok untuk senyawa yang sifatnya termolabil atau tidak tahan akan pemanasan serta dapat menghindari kerusakan zat aktif yang diakibatkan dari 
pemanasan yang dapat menyebabkan kerusakan pada zat aktif yang ditarik. Pada proses maserasi sampel mengalami pemecahan dinding sel dan membran sel akibat perbedaan tekanan antara didalam dan diluar sel sehingga metabolit sekunder yang ada dalam sitoplasma akan terlarut dalam pelarut atau terjadi proses difusi dan melarutkan senyawasenyawa yang memiliki kepolaran yang sama (Hidayah et al., 2014).

Pada penelitian ini menggunakan media NA (Natrium agar) karena media tersebut menunjukan hasil terbaik kemampuanya dalam mendukung pertumbuhan dari berbagai jenis bakteri (Saha, 2008).Pada hasil uji skriningfitokimiaekstrak etanol dauncabairawitspesies Capsicum frutescens Linn dan capsicum annum sama-samamemilikikandungansenyawa tannin, saponin, alkaloid, saponin, fenol, dan flavonoid. Kandungan kimia yang diketahui mempunyai aktivitas antibakteri terdapat pada daun cabai rawitspesiesCapsicum frutescens Linn dan Capsicum annumyang berpotensi sebagai antibakteri dan antijamur yaitu senyawa flavonoid yang dapat bersifat antibakteri. Flavonoid adalah salah satu zat aktif yang berfungsi sebagai obat, flavonoid merupakan golongan terbesar dari senyawa polifenol senyawa flavonoid mempunyai mekanisme kerja sebagai antibakteri dengan cara menghambat sintesis asam nukleat dari sel bakteri, menghambat fungsi dari membran sitoplasma, dan flavonoid juga dapat mengganggu metabolisme energi yang dibutuhkan oleh bakteri sehingga pertumbuhan bakteri terganggu. Senyawa flavonoid mempunyai mekanisme kerja sebagai antijamur yaitu bekerja dengan mendenaturasi protein hingga meningkatkan permeabilitas membran sel. Denaturasi protein menyebabkan gangguan dalam membran sel merubah komposisi komponen protein. Senyawa fenol pada flavonoid dapat mengerutkan dinding dan mendenaturasi protein sel sehingga menyebabkan lisis pada dinding jamur. Selain itu melalui gugus hidroksil pada senyawa fenol akan berikatan dengan protein jamur dan gugus sulfhidril sehingga dapat mengubah konformasi protein sel membran target yang mengakibatkan pertumbuhan seldari jamur akan terganggu hingga mengalami kematian (Noviyanti, 2016).

Hasil uji aktivitas antibakteri dari ekstrak etanol daun cabai rawit spesies Capsicum frutescens Linn terhadap bakteri Staphylococcus aureus memiliki aktivitas di mana pada masing-masing konsentrasi menunjukkan perbedaan daya hambat pada konsentrasi 5\% sebesar 1,6 mm, konsentrasi 10\% sebesar2,5 mm, konsentrasi 20\% sebesar 3,2 mm, dan konsentrasi 40\% sebesar 4,2 $\mathrm{mm}$ masih dikategorikan lemah kerena memiliki nilai $<5 \mathrm{~mm}$. Berdasarkan hasil one-way ANOVA pada bakteri Staphylococcus aureus nilai signifikan $p<0,05$ yaitu sebesar $p=0,00$ yang berarti bahwa ekstrak etanol daun cabai rawit spesies Capsicum frutescens Linn memiliki aktivitas terhadap Staphylococcus aureus.

Pada hasil uji aktivitas antibakteri ekstrak etanol daun cabai rawit spesies Capsicum annum terhadap bakteri Staphylococcus aureus memiliki aktivitas dan masing-masing konsentrasi menunjukkan perbedaan zona hambat dari tiap kosentrasi, pada konsentrasi $5 \%$ sebesar 5,8 $\mathrm{mm}$ di kategorikan sedang, konsentrasi $10 \%$ sebesar $7,8 \mathrm{~mm}$ di kategorikan sedang, konsentrasi 20\% sebesar 13,0 mm dikategorikan sedang, konsentrasi 40\% sebesar 20,2 $\mathrm{mm}$ dikategorikan kuat. Berdasarkan hasil one-way ANOVA pada bakteri Staphylococcus aureus nilai signifikan 
$p<0,05$ yaitu sebesar $p=0,00$ yang berarti bahwa ekstrak etanol daun cabai rawit spesies Capsicum annum memiliki aktivitas terhadap Staphylococcus aureus.

Zona hambat paling besar ditunjukkan pada control positif Tetrasiklin sedangkan zona hambat control negatif DMSO dikategorikan tidak beraktivitas ini sesuai dengan literature bahwa DMSO tidak mempunyai kemampuan sebagai antibakteri sehingga tidak dapat menghambat pertumbuhan bakteri (Setiabudy, 2007).

\section{KESIMPULAN}

Ekstrak etanol daun cabai rawit spesies Capsicum frutescens Linn memiliki aktivitas terhadap Staphylococcus aureus pada konsentrasi 5\%, 10\%, 20\% dan 40\%. Ekstrak etanol daun cabai rawit spesies Capsicum annum memiliki aktivitas terhadap Staphylococcus aureus pada kosentrasi 5\%, 10\%, 20\%, dan 40\%.

\section{DAFTAR PUSTAKA}

Doughari, J.H., 2012, Phytochemicals: Extraction Methods, Basic Structures and Mode of Action as Potential Chemotherapeutic Agents, Phytochemicals -A Global Perspective of Their Role in Nutrition and Health, Intech.

Hidayah. T, Pratjoo. W Dan Widiarti, N., 2014. Uji Stabilitas Pigmen Dan Antioksidan Ekstrak Zat Warna Alami Kulit Buah Naga. Indonesian Jurnal of Chemical Science, 3(2).

Isrul, M., Juliansyah, R., Saleh, A., Yuliastri, W.O., Pusmarani, J. and Maulidina, W.O.W., 2019. Phytochemical Analysis, Standardization and Cytotoxic Activity of Curcuma aureginosa Extract in Human Breast Cancer (MCF-7) Cell Line. Research Journal of Pharmacy and Technology, 12(4), pp.1967-1973.

Jawetz, Melnick, Adelberg., 2005. Medical microbiology. 23th Edition. USA: Mc Graw Hill Company.

Leboffe. M. J and B. E. Pierce., 2011. A Photographic Atlas for the
Microbiology Laboratory, 4th Edition. Morton Publishing Company. United States of America.

Martono, T., Gogot, H., Dewi, G., dan Fendy, A. P. 2012. Ekstraksi Tanin Sebagai Bahan Pewarna Alami Dari Tanaman Putri Malu (Minosa Pidica) Menggunakan Pelarut Organik. Reaktor, 14 (1): 39-45

Noviyanti., 2016. Uji Aktivitas Antifungi Ekstrak Etanol Gel Manjakani (Quercus Infectoria) Terhadap Candida Albicans. Jurnal Ilmiah Mahasiswa Pendidikan Biologi. Unsyiah.

Ortez, J.H. 2005. Disk Diffusion Testing in Manual of Antimicrobial SusceptibilityTesting. Marie B. Coyle (Coord. Ed). American society for Microbiology.

Rahardjo, M., Koendhori, E. B., \&Setiawati, Y. 2018. Uji Aktivitas Antibakteri Ekstrak Etanol Lidah Buaya (Aloe Vera) Terhadap Bakteri Staphylococcus Aureus Pendahuluan Staphylococcus Aureus (S.Aureus) Adalah Bakteri Kokus Gram Positif.

Sugianto. 2012. Pembuatan Medium. UGM;Yogyakarta

Tong SYC, Davis JS, Eichenberg E, Holland TL, Fowler VG. 2015. Staphylococcus aureus infections: Epidemiology, pathophysiology, clinical manifestations, and management. Clinical Microbiology Reviews, 28 (3): 603-661.

Zeller. J.L., 2011. MRSA infections. The Journal of the American Medical Association, 306 (16): 1818. 